\title{
Membaca Serat Gembring Baring Karya Raden Ronggo Prawirodirjo III: Sebuah Ikhtiar Pencarian Pemimpinan Idaman Rakyat
}

\author{
Akhlis Syamsal Qomar, Warto, Akhmad Arif Musadad \\ Universitas Sebelas Maret \\ akhlissyamsal9@student.uns.ac.id
}

\section{Article History}

received $1 / 9 / 2021$

\begin{abstract}
The old manuscript is one of the cultural heritages of the Indonesian nation which is full of noble values. One of the old literary works that has the function of piwulang is Serat Serat Gembring Baring by Raden Rangga Prawiradirja III [Madiun Regent 1796-1810]. The purpose of this study is to describe the leadership concepts contained in the Serat Gembring Baring in order to answer one of the mistakes of our state management, namely, the leadership crisis so that we can find the criteria for an ideal leader and what the people want. The content analysis method is used to reveal the leadership concept contained in the fiber, while the approach used is a historical-descriptive approach. A good leader in Fiber Gembring Baring is a leader who has the following criteria: kan் nĕdya hulah praja (seriously government the country), madẹp kawulannira (pay attention to the people), mantěp maran hadabbin nagari (be loyal to the adab [rules] of the country).
\end{abstract}

Keywords: Baring Gembring Fibersby Raden Rangga Prawirodirja III, the ideal leader of the people

\begin{abstract}
Abstrak
Naskah lama merupakan salah satu peninggalan budaya bangsa Indonesia yang sarat akan nilai-nilai adiluhung. Salah satu karya sastra lama yang mempunyai fung sebagai piwulang adalah Serat Serat Gembring Baring karya Raden Rangga Prawiradirja III [Bupati Madiun 17961810]. Tujuan dari penelitian ini adalah untuk mendeskripsikan konsep-konsep kepemimpinan yang ada di dalam Serat Gembring Baring guna menjawab salah satu kesalahan manajemen kenegaraan kita yaitu, krisis kepemimpinan sehingga dapat menemukan kriteria pemimpin yang ideal dan diidamkan rakyat. Metode analisis isi dipergunakan untuk mengungkap konsep kepemimpinan yang terdapat di dalam serat, sedangkan pendekatan yang digunakan yaitu pendekatan historis-deskriptif. Pemimpin yang baik dalam Serat Gembring Baring adalah pemimpin yang memiliki kriteria yaitu: kań nědya hulah praja (bersungguh-sungguhlah mengatur negara), maḍĕp kawulannira (memperhatikan kepada rakyatnya), dan mantěp marań hadabbin nagari (setia kepada adab [aturan] negeri).
\end{abstract}

Kata kunci: Serat Serat Gembring Baring karya Raden Rangga Prawirodirja III, pemimpin idaman rakyat

Social, Humanities, and Education Studies (SHEs): Conference Series https://jurnal.uns.ac.id/shes 


\section{PENDAHULUAN}

Budaya masa lalu sejatinya simpanan tersembunyi yang mengandung nilai-nilai kehidupan manusia dan perlu digali guna sebagai pedoman dalam kehidupan sekarang dan yang akan datang. Hal itu dianalogikan sebagai refleksi permukaan danau yang tipis dari sebuah danau yang sangat dalam. Di bawah permukaan danau tersebut tersembunyi simpanan pengetahuan budaya yang sangat banyak yang tidak mudah dilihat. Meskipun tersembunyi, pengetahuan budaya tersebut menjadi unsur yang sangat mendasar karena manusia menggunakannya sepanjang masa untuk membentuk perilaku dan menginterpretasikan pengalaman-pengalamannya.

Kebudayaan sejatinya keseluruhan sistem gagasan, tindakan dan hasil karya manusia dalam rangka kehidupan masyarakat yang dijadikan miliknya dengan belajar (Koentjaraningrat, 1990:5). Sedangkan Tylor memaknai kebudayaan sebagai keseluruhan kompleks termasuk di dalamnya pengetahuan, kepercayaan, kesenian, moral, hukum, adat-istiadat, dan segala kemampuan dan kebiasaan lain yang diperoleh manusia sebagai anggota masyarakat (Tylor, 1871). Kebudayaan, berdasarkan pengertian tersebut, terbentuk tidak terlepas dari nilai-nilai agama, karenanya kebudayaan adalah kehidupan dan kemanusiaan dan seluruh proses perkembangan hidup manusia di dalam sejarahnya (Moertopo, 1978:10).

Salah satu hasil dari budaya adalah karya sastra. Sebagai warisan kebudayaan, sastra lama juga dapat mengungkapkan informasi tentang hasil budaya pada masa lampau melalui teks klasik yang dapat dibaca dalam peninggalan-peninggalan yang berupa tulisan atau naskah (Baried, 1983:8). Di Jawa, naskah yang masih berupa teks tulisan tangan atau yang sudah dalam bentuk salinan disebut sebagai serat (Darusuprapto, 1985:193). Adapun isi (content) dari serat itu sebagian besar memuat ajaran (piwulang) dan nasihat (pitutur). Sudewa menyebut karya-karya semacam itu sesuai dengan isinya, sebagai sastra piwulang (Sudewa, 1991:13). Wulang berarti ajaran atau didaktik (Prabowo, 2007:336). Baik sastra piwulang maupun jenis karya sastra yang lain, sama-sama mempunyai fungsi menyampaikan kebenaran, hanya saja dalam sastra piwulang, kebenaran ditampilkan secara diskursif, sedangkan dalam sastra yang lain secara representasional (Wellek \& Warren, 1956:35).

Ajaran-ajaran yang dimuat dalam naskah Jawa terentang mulai dari esoterisme mistik Islam (tasawuf) (Simuh, 2016) hingga etika-moralitas kepemimpinan (Poerbatjaraka \& Hadidjaja, 1952:97). Salah satu naskah Jawa yang memuat ajaran kepemimpinan adalah Serat Gembring Baring karya Raden Rangga Prawiradirja III, seorang Bupati Madiun sekaligus Bupati Wedana mancanegara wetan wilayah Kesultanan Yogyakarta 1796-1810. Serat Gembring Baring sebagaimana jenis seratserat piwulang lainnya, seperti Serat Wulangreh- memuat petunjuk sikap moral bagi seorang yang dipimpin maupun yang memimpin atau seorang pemimpin (Kartodirdjo et.al, 1988:22-23). Bertolak dari paparan di atas, penulis mencoba mengkaji kepemimpinan yang terdapat dalam Serat Gembring Baring sebagai upaya memperkaya khazanah penelitian sastra lama. Tujuan dari penelitian ini adalah untuk mendeskripsikan konsep-konsep kepemimpinan yang ada di dalam Serat Gembring Baring guna menjawab salah satu kesalahan manajemen kenegaraan kita yaitu, krisis kepemimpinan sehingga dapat menemukan kriteria pemimpin yang ideal dan diidamkan rakyat.

\section{METODE}

Penelitian ini menggunakan teori Hermeneutika yang bermakna menunjuk pada ilmu interpretasi, khususnya prinsip-prinsip penafsiran tekstual (Palmer, 1969:13). Adapun hermeneutika yang hendak digunakan dalam penelitian ini adalah hermeneutika teoretis, yang menitikberatkan kajiannya pada cara memahami teks melalui rekonstruksi makna sebagaimana yang dimaksud oleh penggagas teks. Pendekatan yang digunakan dalam penelitian ini adalah pendekatan historis-deskriptif, 
suatu prosedur pemecahan masalah dengan mempergunakan data atau informasi masa lalu yang bernilai sebagai peninggalan (Nawawi \& Martini, 1996214). Pendekatan ini digunakan sebab lebih relevan dalam kerangka sejarah sastra tradisional, sejarah sastra dengan implikasi pengarang, karya sastra, dan periodeperiode tertentu, dengan objek karya-karya sastra individual (Ratna, 2013:66). Sedangkan metode yang dipakai dalam penelitian ini adalah meliputi metode pengumpulan data dan metode analisis data. Metode analisis isi dipergunakan untuk mengungkap konsep kepemimpinan yang terdapat di dalam Serat Gembring Baring.

\section{HASIL DAN PEMBAHASAN}

1. Biografi Raden Rangga Prawiradirja III, sekitar 1779-1810

Raden Rangga Prawiradirja III adalah seorang putra Madiun yang lahir pada sekitar 1779. la merupakan putra dari Bupati Madiun, Raden Rangga Mangundirjo (menjabat antara 1784-1796) atau yang lebih dikenal sebagai Raden Rangga Prawiradirja II. Raden Rangga Prawiradirja III dari ayahnya, terhitung sebagai cucu dari seorang "jawara” (gegedhug) Sukowati bernama Kiai Rangga Wirosentiko yang mempunyai nama kecil Gatha, kelak bergelar Raden Rangga Prawiradirja I (Babad Giyanti). la dalam Serat sarasilah para leloehoer ing Kadanoeredjan dikenal sebagai Rangga Djegot. Tokoh terakhir tidak lain merupakan seorang panglima pasukan Hamengkubuwono I masa Perang Mangkubumen (1747-55) dan Bupati Madiun sekaligus merangkap sebagai Bupati Wedana mancanegara wetan wilayah Kesultanan Yogyakarta (sekitar 1760-1784). Melalui ibunya, Raden Rangga Prawiradirja III masih terhitung sebagai cucu dari Sultan Yogyakarta yang pertama sebab sang ayah menikahi Bendoro Raden Ayu Rangga Mangundirjo, salah seorang putri dari Sultan Hamengkubuwono I (bertakhta 1749-1792) dari selirnya yaitu, Bendara Raden Ayu Srenggoro dari trah Kedu (Serat sarasilah para leloehoer ing Kadanoeredjan).

Rangga Prawiradirja III diketahui menikah dengan Gusti Kanjeng Ratu Maduretno, putri Sultan Hamengkubuwono II dengan Ratu Kedaton yang berdarah Madura pada akhir dasawarsa 1790-an (Bribin, 2014). Ikatan perkawinan Rangga III sebagai Bupati Madiun dan Bupati Wedana mancanegara wetan dengan Ratu Maduretno putri Sultan Hamengkubuwono II Yogyakarta, sangat penting secara politik yaitu untuk mempertahankan loyalitas penguasa lokal terhadap Sultan di Yogyakarta. Akan tetapi, perkawinan Rangga III dengan Ratu Maduretno menjadi pemicu pemberontakan daripada loyalitas kepada Sultan Hamengkubuwono II Yogyakarta (Carey, 2012:256). Rangga III merupakan menantu terhormat Sultan Hamengkubuwono II yang diangkat menjadi salah satu penasehatnya. Sehingga dalam keseharian Rangga III lebih banyak menghabiskan waktunya di Keraton Yogyakarta selain mempunyai kediaman di Wonosari dan Maospati (Adam, 1940:334).

Rangga Prawiradirja III dikenal sebagai seorang pengarang satu diantara dongeng-dongeng seri cerita Damar Wulan yang terkenal di Jawa. "Raden Rangga Prawiradirja, inggih punika ingkang nyambeti nganggit serta Damarwulan, wiwit Damarwulan kabegal" (Babad Alit). Rangga III juga dikenal memiliki hubungan dekat dengan banyak guru agama dan haji di kawasan Madiun dan Ponorogo serta tokoh agama lain dalam kelompok pendukung dekatnya di Maospati (Bundel Djokja Brieven", (Dj Br) no. 409). Menurut Babad Pacitan, guru agama Rangga ialah seorang kiai dari wilayah Pacitan yang dikenal dengan Kiai Kaliyah, yang berpengaruh besar terhadap dia. Rangga III disebut mendanai suatu desa perdikan Giripurno di Gunung Bancak (Rancang Kencono) untuk merawat makam istri kinasihnya Gusti Kanjeng Ratu Maduretno yang meninggal pada 16 November 
1809 dan membangun masjid di tempat tinggalnya di Maospati (Kota Petik) yang cukup banyak menyimpan karya-karya keagamaan. (Adam, 1940).

Persentuhan dan pemahaman Raden Rangga Prawiradirja III terhadap karya-karya sastra lama Jawa mengilhami dirinya ketika ia memimpin perlawanan terhadap pemerintah kolonial Belanda tahun 1810. Rangga berkhayal bahwa dirinya adalah Batara Guru, dewa pengayom dalam wayang yang disegani semua tokoh lain. la juga mengambil teladan dari kisah Ramayana ketika tiba saatnya ia mengangkat para panglima tentaranya di Madiun pada akhir November. Karenanya jenderal utama di beri nama "Dosomuko", suatu julukan bagi rajaraksasa Lanka (Sailan), Rawana, dalam kisah Ramayana, dan deputinya diberi nama sa maran perang (nom -de-guerre) Dirgananda (Carey, 2012:287).

Rupanya Raden Rangga termotivasi untuk membuat sebuah monument berupa karya sastra yang terus dikenang sampai jauh setelah masa penciptanya meninggal lazimnya. Karya monumentalnya, yang salah satu versinya tersimpan di Perpustakaan Universitas Leiden, Belanda, adalah Serat Gembring Baring. Naskah ini berkode LOr 65171, terdiri atas 2 teks yaitu Serat Centhini dan Serat Gembring Baring. Naskah ini dulunya merupakan milik Pangeran Sasraningrat yang dikenal sebagai Pakualam III (1858-1864). Naskah ini merupakan salah satu dari tiga yang berisi Serat Gembring Baring yang tertua selain naskah berkode PB A.241 (1858) koleksi Museum Sonobudoyo Yogyakarta dan naskah berkode W 305 (1858) koleksi Widyapustaka Kraton Yogyakarta. Nama lain Serat Gembring Baring adalah Kidung Perlambang dan Serat Sipatulwijrah.

Gembring secara harfiah berarti rusak, gila atau edan. Kata baring memiliki arti yang sama dengan gembring. Gembring Baring (Bahasa Jawa) merupakan tembung saroja yaitu dua kata yang artinya sama yang digunakan secara bersama sama. Tembung saroja misalnya budi pekerti, gotong royong, babak bundhas, dll. Serat Gembring Baring di dalam naskah koleksi Perpustakaan Universitas Leiden dengan kode LOr 6517 terdiri atas lima pupuh. Pupuh 1 Tembang Sinom 33 bait, pupuh 2 Tembang Dhandhanggula 31 bait, pupuh 3 Tembang Pangkur 58 bait, pupuh 4 Tembang Durma 107 bait, pupuh 5 Tembang Dhandhanggula 25 bait. Tiga bait dalam pupuh 5 Tembang Dhandhanggula terkait erat dengan konsep kepemimpinan Jawa yang masih relevan dimasa sekarang.

2. Konsep Kepemimpinan dalam Serat Gembring Baring

Konsep dapat dimaknai sebagai ide atau pengertian yang diabstrakkan dari peristiwa konkrit, atau gambaran mental dari objek, proses, atau apa pun yang ada di luar bahasa dan digunakan oleh akal budi untuk memahami hal-hal lain. Dengan pengertian lain, konsep merupakan suatu rancangan yang amat bernilai untuk melakukan suatu pekerjaan, sehingga pekerjaan yang dilaksanakan tersebut dapat terprogram dan terarah dan pada gilirannya hasil dan tujuan yang diinginkan akan mudah tercapai dengan baik, terarah, dan terukur.

Kepemimpinan adalah sifat yang melekat pada seorang pemimpin. Setiap manusia pada hakikatnya adalah pemimpin, minimal pemimpin dirinya sendiri; pemimpin keluarga, masyarakat, bangsa dan pemimpin negara. Keteladanan pemimpin dalam berbagai sektor sangat dibutuhkan dan sangat menentukan keberhasilannya sebagai pemimpin. Terutama pemimpin bangsa yang menjadi teladan seluruh masyarakt. Segala tingkah laku dan perbuatannya dapat menimbulkan kesadaran perilaku individu maupun kolektif, selaras dengan prinsipprinsip kepemimpinan yang disepakatinya. Keadaan tersebut dapat merupakan kekuatan besar dan dambaan bersama dalam rangka menciptakan bangsa yang jaya, berwibawa, berbudaya dan beradap, jauh dari sifat biadab.

Seseorang pemimpin yang ideal haruslah mempunyai karakteristik: (1) memiliki kekuatan jasmani dan rohani, (2) memiliki semangat dan antusias untuk mencapai tujuan, (3) ramah tamah dan penuh perasaan, (4) cerdas, (5) dapat 
mengambil keputusan, (6) memiliki kecakapan mendidik dan mengajar, (7) jujur dan adil, (8) memiliki kebenaran, penuh keyakinan dan percaya diri, (9) ulet dan tahan uji, (10) suka melindungi, (11) penuh inisiatif, simpatik, dan memiliki daya tarik, (12) bergairah dalam bekerja dan bertanggung jawab, (13) waspada, rendah hati, dan objektif (Fattah, 2001:90).

Budaya Jawa dimasa lalu mengenal kepemimpinan bersifat absolut atau penguasa tunggal. Raja bukan saja pembuat hukum, bahkan ia sendiri adalah hukum. Konsep kekerasan dan kesewenang-wenangan harus dilakukan oleh seorang pemimpin atau raja pada waktu itu karena untuk menjawab berbagai persoalan kemasyarakatan memang keras dan harus mengandalkan kekuasaan. Konsep kesewenang-wenangan tersebut memudar setelah Islam masuk ke tanah Jawa. Konsep absolut berubah menjadi rahmatan lil alamin, yaitu pemimpin atau raja harus menjadi penasihat, teladan, pengayom, dan pelindung rakyat dan negara. Selain itu pengaruh Islam juga terlihat dalam konsep-konsep kepemimpinan seorang raja dalam mengatur Negara atau kerajaan.

Raden Rangga Prawiradirja III dalam Serat Gembring Baring menyebutkan bahwa bahwa seorang pemimpin hendaknya senantiasa bersungguh-sungguhlah mengatur Negara, memperhatikan kepada rakyatnya, dan setia kepada adab [aturan] negeri. sebagaimana terdapat dalam bat 1, 18, dan 21 pupuh 5 Tembang Dhandhanggula di bawah ini:

kań nĕdya hulạ̣ praja

maḍĕp kawulannira

mantěp marań hadabbiń nagari

bersungguh-sungguhlah mengatur Negara

memperhatikan kepada rakyatnya

setia kepada adab [aturan] negeri

Tembang Dhandhanggula di atas menunjukkan bahwa setidaknya ada tiga kriteria yang harus dimiliki oleh seorang pemimpin, yaitu: kan nĕdya hulah praja, maḍĕp kawulannira dan mantĕp marań hadabbin nagari.

Kań nědya hulah praja artinya 'bersungguh-sungguhlah mengatur Negara'. Hal tersebut dapat dimaknai bahwa seorang pemimpin haruslah serius mengatur Negara dan tidak boleh terbujuk dengan godaan-godaan sesaat. Seorang pemimpin ketika masih dalam masa jabatannya, hal biasa terjadi tergoda oleh kepentingan sesaat, misalnya tergoda oleh wanita. Salah satu jalan keberhasilan seorang pemimpin adalah ketika ia berhasil menjaga dirinya dari godaan wanita.

Maḍĕp kawulannira artinya 'memperhatikan kepada rakyatnya'. Piwulang ini dapat dimaknai bahwa seorang pemimpin harus senantiasa memperhatikan rakyatnya khususnya rakyat kecil. Seorang pemimpin tidak boleh hanya memetingkan kepentingan keluarga dan kelompoknya. la diharapakan bisa mengayomi semua rakyatnya.

Mantĕp marań hadabbiń nagari artinya 'setia kepada adab [aturan] negeri'. Masih berkaitan dengan piwulang pada bait sebelumnya, salah satunya seorang pemimpin tidak boleh terbujuk dengan godaan-godaan sesaat misalnya, memperkaya diri dan kelompoknya dengan tindak pidana korupsi. Hal tersebut merupakan sikap tidak setia atau patuh terhadap aturan Negara yang berlaku. Sehingga diharapkan dengan patuhnya seorang pemimpin kepada aturan Negara yang berlaku dapat menjadi teladan bagi rakyatnya untuk melakukan hal yang sama.

Tiga konsep kepemimpinan Jawa dalam Serat Gembring Baring di atas erat kaitannya dengan bangsa di sepanjang Nusantara ini yang telah memproklamasikan kemerdekaannya sebagai Bangsa Indonesia. Sekarang bangsa ini telah merdeka lebih dari 76 tahun atau lebih setengah abad. Bahkan telah melewati tiga fase kritis: fase perjuangan fisik untuk keluar dari belenggu 
penjajah 1945, fase revolusi tahun 1966, dan fase reformasi tahun 1998. Namun, tanda-tanda kemakmuran seluruh tumpah darah Indonesia masih jauh dari harapan.

Dengan kondisi real tersebut di atas berarti ada yang salah dalam manejemen kenegaraan kita. Kesalahan tersebut yang berakibat kepada keterpurukan Indonesia hingga jatuh kelembah krisis multi dimensional. Seperti: krisis keuangan, krisis kepercayaan, krisis kepemimpinan, krisis keamanan, krisis sistem pendidikan, bahkan pernah terjadi krisis pangan. Walaupun telah dibentuk KPK (Komisi Pemberantasan Korupsi) namun sampai dengan sekarang masih merajalela korupsi, kolusi, da nepotisme di tengah masyarakat. Tentunya merupakan ironi karena ketiga isu ini menjadi faktor utama jatuhnya orde baru dan menjadi pilar bangkitnya fase Reformasi. Untuk keluar dari berbagai masalah di atas tentunya aspek kepemimpinan nasional menjadi faktor yang sangat penting. Bahkan, boleh dikatakan sebagai faktor dominan.

Salah satu buah dari reformasi adalah berubahnya sistem pemilihan umum. Pemilihan umum yang merupakan pesta demokrasi dalam waktu dekat seharusnya disukseskan oleh seluruh komponen bangasa. Kesuksesan pemilihan umum ini, baik berupa pemilihan anggota legislatif maupun pemilihan presiden dan wakil presiden Republik Indonesia; tentunya merupakan momentum yang sangat tepat untuk mengubah wajah Bangsa Indonesia untuk periode 5 tahun mendatang. Kesalahan memilih pemimpin tidak mustahil akan mengembalikan bangsa ini kejurang keterpurukan yang lebih parah dari sebelumnya.

Olehnya sudah saatnya berbagai kompenen bangsa berpartisipasi dalam pemilihan umum tersebut dan menentukan pilihannya sesuai hati nurani. Memilih pemimpin yang memenuhi kriteria kań nědya hulaḥ praja (bersungguh-sungguhlah mengatur negara), maḍ̆p kawulannira (memperhatikan kepada rakyatnya), dan mantĕp marań hadabbiń nagari (setia kepada adab [aturan] negeri) sehingga diharapkan bisa memperbaiki bangsa indonesia menjadi bangsa yang maju, beradab, makmur, adil, dan sejahtera, serta sentosa. Pemimpin yang bisa mengemban amanah tersebut diatas adalah pemimpin idaman seluruh rakyat.

\section{SIMPULAN}

Serat Gembring Baring karya Raden Rangga Prawiradirja III merupakan salah satu jenis sastra wulang yang berisi tentang konsep kepemimpinan yaitu bagaimana menjadi pemimpin ideal dan diidamkan rakyat. Raden Rangga Prawiradirja III dalam karyanya tersebut menuliskan bahwa tersebut pemimpin yang baik adalah pemimpin yang memiliki kriteria yaitu: kań nĕdya hulaḥ praja (bersungguh-sungguhlah mengatur negara), maḍ̆p kawulannira (memperhatikan kepada rakyatnya), dan mantěp marań hadabbin nagari (setia kepada adab [aturan] negeri). Tiga kriteria pemimpin di atas diharapkan dapat menjawab salah satu kesalahan manajemen kenegaraan kita yaitu, krisis kepemimpinan sehingga dapat menemukan kriteria pemimpin yang ideal dan diidamkan rakyat.

\section{DAFTAR PUSTAKA}

Adam, (1940). "Geschiedkundige aantekeningen omtrent de residentie Madioen. VI:Het Tijdek van de 'Palihan' tot 1825", Djawa, No. 20, 334

Baried, Siti Baroroh dkk. (1983). Pengantar Teori Filologi Jakarta: Pusat Pembinaan dan Pengembangan Bahasa. 
Bribin, R.Ay.B. Heny. (2014). Serat Raja Putra Ngayogyakarta Hadiningrat. Yogyakarta: Tiara Wacana Group.

Carey, Peter. (2012). Kuasa Ramalan: Pangeran Diponegoro dan Akhir Tatanan Lama di Jawa, 1785- 1855. Jakarta: KPG bekerja sama dengan KITLV Jakarta.

Darusuprapto, dkk., (1985). Keadaan dan Jenis Sastra Jawa: Keadaan dan Perkembangan Bahasa, Sastra, Etika, Tata Krama, dan Seni Pertunjukan Jawa, Bali dan Sunda. Yogyakarta: Departemen Pendidikan dan Kebudayaan.

Fattah, Nanang. (2001). Landasan Manajemen Pendidikan.Bandung: PT Remaja Rosdakarya.

Kartodirdjo, S. et.al. (1988). Beberapa Segi Etika dan Etiket Jawa. Yogyakarta: Departemen Pendidikan dan Kebudayaan.

Koentjaraningrat. (1990). Manusia dan Kebudayaan Indonesia. Jakarta: Djambatan.

Moertopo, Ali. (1978). Strategi Kebudayaan. Jakarta: Yayasan Proklamasi.

Nawawi, Haidari dan Mimi Martini. (1996). Penelitian Terapan. Yogyakarta: Gadjah Mada University Press.

Palmer, Richard E. (1969). Hermeneutics. Interpretation Theory in Schleiermacher, Dilthey, Heidegger, and Gadamer. Evanston: Northwestern University Press.

Poerbatjaraka dan Tardjan Hadidjaja. (1952). Kepustakaan Jawa. Jakarta: Djambatan.

Prabowo, Dhanu Priyom, dkk. (2007). Glosarium Istilah Sastra Jawa. Yogyakarta: Narasi.

Ratna, Nyoman Kutha. (2013). Teori, Metode, dan Teknik Penelitian Sastra: Dari Strukturalisme hingga Poststrukturslisme Perspektif Wacana Naratif. Yogyakarta: Pustaka Pelajar.

Rene Wellek \& Austin Warren. (1956). Theory of Literature. New York: Harcourt Brace \& Co.

Simuh. (2016). Sufisme Jawa: Transformasi Tasawuf Islam ke Mistik Jawa. Yogyakarta: Narasi.

Sudewa, A. (1991). Serat Panitisastra. Yogyakarta: Dutawacana University Press.

Tylor, Edward B. (1871). Primitive Culture: Research Into The Development of Mithology, Philosophy, Religion, Art, and Custom. London: John Murray. 